\title{
ФОРМУВАННЯ ТА РОЗВИТОК ЛОГІСТИЧНОЇ ІНФРАСТРУКТУРИ УКРАЇНИ В КОНТЕКСТІ ЄВРОІНТЕГРАЦІЇ
}

\author{
Бортнік Світлана Миколаївна \\ кандидат економічних наук, доцент \\ Східноєвропейський національний університет імені Лесі Українки (м. Луцьк, Україна) \\ ORCID: 0000-0003-2687-7866 \\ s-bortnik@ukr.net
}

Bcmyn. Транспортна система України має низький рівень розвитку логістичної інфррастуктури та транспортно-логістичних технологій загалом, що знижує її конкурентоспроможність та обмежує інтеграційні можливості нашої держави у світовому економічному просторі. Україні необхідні термінові заходи для поліпшення транспортно-логістичної інфраструктури, оскільки вона є застарілою, неефективною, потребує оновлення, модернізації, суттєвих інвестиційних вкладень та удосконалення системи управління нею. Існує необхідність адаптувати концепцію удосконалення логістичної інфраструктури до потреб українського ринку транспортно-логістичних послуг.

Метою статті є продемонструвати місце України у світових рейтингах розвитку логістики та логістичної інфрраструктури, а також проаналізувати причини поточних результатів нашої держави в цих рейтингах.

Результати. Встановлено, що транспортно-логістична інфраструктура виступає важливим чинником економічного зростання будь-якої держави. Конкретизовано поняття транспортно-логістичної інфрастуктури та її складових. Дана оцінка загального стану розвитку логістичної інфраструктури в Україні, а також оцінка рівня використання логістичного потенціалу на основі рейтингів глобальної конкурентоспроможності та логістичної ефективності. Проаналізовано місце України в глобальному рейтингу конкурентоспроможності за якістю транспортної інфраструктури, а також динаміку показників логістичної ефективності України, здійснено міжнародні порівняння. Доведено взаємозв'язок позицій у міжнародних рейтингах глобальної конкурентоспроможності та логістичної ефективності із станом та якістю логістичної інфрастуктури в країні.

Висновки. Завдяки проведеному аналізу виявлено чинники, що впливають на функціонування та розвиток транспортно-логістичної інфраструктури України. Доведена необхідність покращення системи управління транспортно-логістичною інфраструктурою. 3 метою забезпечення синергетичного ефекту від ефективного поєднання потенціалу та можливостей усіх видів транспорту управління розвитком транспортно-логістичної інфраструктури повинно бути стратегічно орієнтованим і базуватися на оцінці потенціалу логістичної інфраструктури, виявленні зв'язків та залежності її розвитку від організаційно-економічних, техніко-технологічних та інших можливостей.

Ключові слова: логістика, логістична ефективність, транспортно-логістична інфраструктура, якість логістичної інфрастуктури, управління розвитком транспортно-логістичної інфрраструктури.

DOI: https://doi.org/10.32845/bsnau.2019.3.6

\section{Вступ}

Розвиток транспортно-логістичної інфраструктури є важливим чинником інтеграції України у світовий економічний простір, оскільки вона знижує вплив відстані між країнами на їх економічне зростання, забезпечує інтеграцію національного ринку та зниження вартості транспортування на зовнішні ринки. Як свідчать дослідження фрахівців, створення ефективних логістичних систем забезпечує промислово-розвинутим країнам отримання додатково 15-25 \% валового національного продукту [1].

На наш погляд Україні необхідні термінові заходи для поліпшення транспортно-логістичної інфрраструктури, оскільки галузь потерпає від низького використання виробничих потужностей, неадекватної сучасним потребам інфраструктури та високих витрат. Застаріла транпортно-логістична інфраструктура потребує суттєвої модернізації, яка ставить завдання не лише заміни застарілого обладнання та інженерних споруд, а комплексної та системного їх переобладнання відповідно до нових технологій обробки вантажних потоків. Відповідно актуалізується проблематика досліджень у напрямі удосконалення логістичної інфраструктури в Україні, забезпечення належного інвестування її розвитку.

Значні інфраструктурні проекти супроводжуються інвестиціями в будівництво, а поспіль і в реконструкцію споруд, таким чином викликаючи попит на продукцію суміжних секторів. Так, фахівцями встановлено, що світові потреби в інвестиціях в інсрраструктуру на період з 2013 по 2030 рік складають 57,2 трлн дол. за умови щорічного приросту ВВП на 3-5\% [2]

Актуальність проблем розвитку транспортно-логістичної інфраструктури підтверджується досвідом розвинених країн, в яких активно створюються і удосконалюються регіональні, національні та транснаціональні транспортно-логістичні системи, що забезпечують ефективні транспортні, науково-виробничі та постачальницько-збутові комунікації між економічними агентами [1]. Окрім того, транспортна система України має низький рівень розвитку транспортно-логістичних технологій та об'єктів мультимодальних перевезень, що знижує її конкурентоспроможність та обмежує вихід української продукції на світовий транспортний ринок.

Значна кількість публікацій стосовно вигідного географрічного розташування України та необхідності його використання, міжнародних транспортних коридорів, які проходять нашою країною, низка розроблених проектів повинні були б сприяти розбудові відповідної логістичної інфраструктури держави [3, 4; 5]. Однак, навіть поверхневий розгляд світових рейтингів країн за розвитком логістичної інфрраструктури показує, що наша держава посідає у них доволі скромні позиції. Це актуалізує, відповідно, необхідність аналізування причини такого становища.

Питання формування та функціонування логістичної інфрраструктури, а також шляхи її удосконалення розглядалися провідними науковцями та спеціалізованими науково-дослідними організаціями. Вивченню питань формування і розвитку

Вісник Сумського національного аграрного університету 
транспортно-логістичної інфраструктури присвячено дослідження багатьох видатних вітчизняних (Долішній М., Гуржій Н. М. [2], Карий О. [3], Ковальська Л. Л. [4], Козоріз М., Крикавський Є. [5], Павліха Н. [6], Подвальна Г. [3], Полякова О. [1], Попова Н. [6], Попова Ю., Румянцев А. [8], Тарнавська Н. [9], Чухрай Н., Шостак Л. [10], Шраменко О. [1]) та зарубіжних (Саславський Д, Оджала Л. [13], Окландер М., Шеферд Б. [13], Гласс О. [11]) науковців, які розглядають концепцію логістичної інфраструктури, особливості розвитку об'єктів логістичної інфраструктури в тій чи іншій країні. Вітчизняні дослідники адаптували концепцію логістичної інфрраструктури до потреб українського ринку, однак низка питань щодо формування логістичної інфраструктури та її інтеграції до світової транспортно-логістичної ситеми залишається вікритою.

\section{Мета дослідження}

Метою статті є проаналізувати місце України у світових рейтингах розвитку логістичної інфраструктури, виявити причини положення нашої держави в цих рейтингах, а також виявити чинники, що впливають на функціонування та розвиток транспортно-логістичної інфраструктури.

\section{Виклад основного матеріалу дослідження}

Логістична інфраструктура виступає важливим чинником економічного зростання будь-якої держави, оскільки забезпечує прискорення руху товаропотоків, зниження вартості товарів і послуг, створення нових робочих місць, збільшення обороту торгівлі та підвищення якості обслуговування покупців, а також підвищення інвестиційної привабливості територій з розвиненою транспортно-складською інфрраструктурою, покращення екологічної обстановки завдяки оптимізації транспортної інфраструктури, збільшення доходів держави від реалізації транзитного потенціалу. Розглянемо трактування поняття транспортно-логістичної інфрраструктури (ТЛІ) в сучасній економічній науці.

Так Полякова О. та Прокоф'єва Т. розуміють під поняттям транспортно-логістичної інфраструктури з сукупність транспортних вузлів, магістральних і місцевих шляхів сполучення, контейнерних і вантажопереробних терміналів, мультимодальних транспортно-логістичних центрів, що спеціалізуються на перевезенні вантажів, зберіганні та вантажопереробці, транспортно-експедиційному, логістичному сервісному обслуговуванні та управлінні товарно-матеріальними та супутніми потоками, тісно співпрацюють з науковими, освітніми установами, органами державної та регіональної влади з метою підвищення конкурентоспроможності на вітчизняному та світовому ринку транспортно-логістичних послуг [1]. Таке розуміння цілком виправдане, однак, на наш погляд транспортно-логістична інфраструктура включає не лише сукупність транспортних вузлів, магістральних і місцевих шляхів сполучення, терміналівта транспортно-логістичних центрів, а й систему засобів просторово-часового перетворення логістичних потоків та сукупність обслуговуючих транспортно-логістичних підприємств.

О.Карий, Г.Подвальна трактують логістичну інфрраструктуру як комплекс інфраструктур, які обслуговують логістичну діяльність, і включають інфрраструктуру автомобільного транспорту, залізничну інфраструктуру, інфрраструктуру авіаційного транспорту, інфраструктуру морського і річкового транспорту, трубопровідну інфраструктуру, складську та телекомунікаційну інфраструктуру [3]. Наведене визначення є більш ширшим розумінням, оскільки, ТЛІ - це дійсно комплекс інфрраструктур.
Є.Крикавський розглядає логістичну інфраструктуру, як цілісну систему управління (сукупність будівель, споруд 3 необхідним обладнанням для складування продукції, транспортні та маніпуляційні засоби, засоби пакування, засоби отримання, передачі та обробки інформації). Науковець вважає, що логістична інфраструктура - це сукупність елементів, що виконують важливі логістичні завдання і забезпечують здійснення логістичних процесів [5, с.52]. Цілісну господарську систему утворення, транспортування, збору, складування, сортування, сертифікації та ідентифікації, реалізації, утилізації та рециклінгу з елементами відповідного обслуговування, а саме інформаційного, маркетингового, транспортного, комерційного тощо називає логістичною інфраструктурою Н. Павліха. [6].

Виходячи із зазначеного, під транспортно-логістичною інфрастуктурою можна розуміти систему засобів просторово-часового перетворення логістичних потоків та сукупність підприємств, що забезпечують організаційно-економічні умови проходження цих потоків та раціоналізацію транспортно-складських процесів, матеріальних, фінансових та інформаційних потоків у сфері обігу. Складовими цієї інфрраструктури є транспортна, складська, транскордонна, інформаційна, фінансова та забезпечуюча складові інфраструктури. Це інтегрована багаторівнева та багатофункціональна сукупність суб'єктів транспортно-логістичної діяльності та об'єктів транспортно-логістичної інфраструктури країни, що взаємодіють між собою з метою оптимізації руху вантажопотоків за мінімальних витрат на максимально вигідних умовах, та забезпечує якісне надання транспортно-логістичних послуг.

В дослідженні експертів Світової організації торгівлі доведено розрахунками, що якість транспортної інфраструктури впливає на сукупний обсяг міжнародної торгівлі і є фактором результативності торговельної діяльності. Зокрема, торгівля з експортоорієнтованою країною в майбутньому призводить до збільшення двосторонньої торгівлі на 15\% [11]. 3 іншого боку, зростання ВВП країни залежить від зростання вартості основних фондів і зайнятості населення. Розвиток інфраструктури перевезень та розширення асортименту транспортних послуг впливає, таким чином, на зростання питомої ваги капіталу та праці в доходах країни.

У 2017-2018 роках Кабінетом Міністрів України схвалено Національну транспортну стратегію України на період до 2030 року, метою якої є розвиток безпечного, екологічно чистого та енергоефективного транспорту. Для реалізації означеної Стратегії у 2018 року затверджений План заходів щодо реалізації Стратегії, який містить 58 кроків, одним з яких $€$ затвердження Державної програми підвищення рівня безпеки дорожнього руху в Україні та сприяння розробленню безпечної нової інфраструктури шляхом урахування всіх видів транспорту під час будівництва нової інфраструктури, установлення високого рівня безпеки у технічних характеристиках нових проектів, урахування досвіду виконання програм безпечної інфраструктури.

Стратегія визначає пріоритетні напрями покращення якості надання транспортних послуг, передбачає наближення рівня їх надання та розвитку інфраструктури до європейських стандартів, підвищення рівня безпеки та зменшення негативного впливу на довкілля, реагує на необхідність покращення системи управління, проведення адміністративної реформи та децентралізації завдань і функцій центральних органів викона-

Вісник Сумського національного аграрного університету 
вчої влади, запровадження антикорупційної політики, корпоративного управління у державному секторі економіки.

Як відомо для оцінки загального стану розвитку логістичної інфраструктури в Україні, а також оцінки рівня використання логістичного потенціалу, можна скористатись аналізом даних рейтингів глобальної конкурентоспроможності та логістичної ефективності, що виводяться Світовим банком. Зазначимо, що Індекс логістичної ефективності (Logistics Performance Index, LPI) використовується для вимірювання ефективності міжнародних ланцюгів поставок. У дослідженнях беруть участь понад 160 країн світу, які оцінюються за п'ятибальною системою і за кількома окремими характеристиками [13]: Infrastructure - наявність і якість торговельної та транспортної інфраструктури (порти, залізниці, автомобільні дороги, інформаційні технологіiі); Customs - ефективність роботи митниці та митного контролю; International shipment - простота організації за конкурентними цінами міжнародних перевезень вантажів; Logistics competence - компетентність фахівців в сфрері логістики та якість логістичних послуг; Tracking \& tracing - здатність відстежувати та виявляти стан, місцезнаходження і фракт доставки вантажу; Timeliness - частота відправлень, своєчасність і надійність доставки. Завдяки цьому індекс ефективності логістики (LPI) є інструментом інтерактивного еталонного тестування, який створений, щоб допомогти країнам визначити проблеми та можливості, з якими вони стикаються у своїй діяльності у сфрері торгівельної логістики, і що вони можуть зробити для підвищення їх ефективності.
Минулого року Всесвітній Банк опублікував рейтинг Logistics Performance Index 2018, який дозволяє проводити порівняння ефективності логістики в 160 країнах. LPI заснований на всесвітньому опитуванні операторів на місцях (глобальні експедитори та експрес-перевізники), які надають відгуки щодо «доброзичливості» логістики країн, в яких вони працюють, і тих, з якими вони провадять торгівельну діяльність. Вони поєднують достатньо глибокі знання практичного спрямування про країни, в яких вони працюють, з поінформованими якісними оцінками інших країн, з якими співпрацюють в ссрері торгівлі та мають досвід оцінювання глобального логістичного середовища. Таким чином, LPI складається як 3 якісних, так і кількісних показників, вимірює продуктивність уздовж логістичного ланцюга поставок в країнах і допомагає створювати профілі логістичної ефективності цих країн.

Згідно з даними звіту "Глобальний індекс конкурентоспроможності 2015-2016" порівняно з минулим періодом Україна втратила 3 позиції та посіла 79 місце серед 160 країн світу, а у 2017 знизилась ще на 1 позицію [14]. Основними причинами такої ситуації експерти вважають погіршення якості інфраструктури доріг, портової інфраструктури, а також якість інфрастуктури залізничного, морського та повітряного транспорту. За якістю дорожнього покриття Україна займає 128 місце із 168 країн, що беруть участь у визначенні рейтингу. Натомість у 2018 році за даними Світового банку позиції нашої країни дещо покращилися у рейтингу (підняття на 11 пунктів), що є досить позитивним явищем.

Таблиця 1

Місце України в глобальному рейтингу конкурентоспроможності за якістю транспортної інфраструктури

\begin{tabular}{|l|c|c|c|c|c|}
\hline \multirow{2}{*}{ Показники } & \multicolumn{5}{c|}{ Роки проведення рейтингу } \\
\cline { 2 - 6 } Кількість країн-учасників & $2012-2014$ & $2014-2015$ & $2015-2016$ & $2016-2017$ & $2017-2018$ \\
\hline Індекс глобальної конкурентоспроможності & 155 & 160 & 140 & 160 & 160 \\
\hline Транспортна інфрраструктура & 66 & 61 & 79 & 80 & 69 \\
\hline - якість усієї інфраструктури & 87 & 88 & 91 & 91 & 92 \\
\hline - якість доріг & 77 & 75 & 82 & 88 & 84 \\
\hline - якість залізничної інфраструктури & 135 & 139 & 132 & 134 & 128 \\
\hline - якість портової інфрраструктури & 26 & 25 & 28 & 34 & 32 \\
\hline - якість інфраструктури повітряного транспорту & 101 & 107 & 108 & 96 & 92 \\
\hline LOGISTICS PERFORMANCE INDEX & 95 & 99 & 97 & 103 & 96 \\
\hline Місце України у рейтингу & 2,85 & 2,98 & 2,88 & 2,84 & 2,83 \\
\hline
\end{tabular}

Джерело: складено автором на основі [14]

Динаміка показників логістичної ефективності України за 2007 - 2018 роки показує ідентичні тенденції (табл.2). Всього рейтинг включає п'ять напрямків, за якими проведені дослідження. У розділі "митні процедури" Україна набрала у 2018 році 2,49 бала, по інфраструктурі - 2,22 бала, по міжнародному транспортуванню вантажів - 2,83 бала, по логістичній компетентності - 2,84 бала, з відстеження вантажів - 3,11 бала, по своєчасності доставки - 3,42 бала. Чим вище бал, тим сильніші позиції в країни в даній категорії.

Позиції Україні в глобальному рейтингу логістичної ефективності погіршились за 2007 - 2010 роки, а також за 2014 - 2016 рр. За індексом логістичної ефективності у 2016 році Україна в рейтингу займала 80 місце, тоді як у 2018 році, коли спостерігалося покращення показників економічного розвитку, Україна зайняла 66 позицію [15].

Динаміка показників логістичної ефективності України (2007-2018рр.)

\begin{tabular}{|c|c|c|c|c|c|c|c|c|c|c|c|c|}
\hline \multirow{2}{*}{ Показники } & \multicolumn{2}{|c|}{2007} & \multicolumn{2}{|c|}{2010} & \multicolumn{2}{|c|}{2012} & \multicolumn{2}{|c|}{2014} & \multicolumn{2}{|c|}{2016} & \multicolumn{2}{|c|}{2018} \\
\hline & місце & бал & місце & бал & місце & бал & місце & бал & місце & бал & місце & бал \\
\hline Інтегральний індекс & 73 & 2,55 & 102 & 2,57 & 66 & 2,85 & 61 & 2,98 & 80 & 2,74 & 66 & 2,83 \\
\hline Якість митних процедур & 97 & 2,22 & 135 & 2,02 & 88 & 2,41 & 69 & 2,69 & 116 & 2,3 & 110 & 2,49 \\
\hline Інфраструктура & 74 & 2,35 & 79 & 2,44 & 70 & 2,69 & 71 & 2,65 & 84 & 2,49 & 81 & 2,22 \\
\hline Міжнародні відправлення & 83 & 2,53 & 84 & 2,79 & 83 & 2,72 & 67 & 2,95 & 95 & 2,59 & 98 & 2,83 \\
\hline Компетентність & 90 & 2,41 & 77 & 2,59 & 61 & 2,85 & 72 & 2,84 & 95 & 2,55 & 99 & 2,83 \\
\hline Контроль & 81 & 2,53 & 112 & 2,49 & 50 & 3,15 & 45 & 3,2 & 61 & 2,96 & 75 & 3,11 \\
\hline Своєчасність & 55 & 3,31 & 114 & 3,06 & 68 & 3,31 & 52 & 3,51 & 54 & 3,51 & 58 & 3,42 \\
\hline
\end{tabular}

Джерело: складено автором на основі [15] 
32007 по 2018 рр. динаміка показника LPI по Україні була такою: найбільший показник країна продемонструвала 2014 р. (61-е місце, 2,98 бала), найменший - 2010 р. (102-е місце, 2,57 бала; хоча у 2007 р. країна посіла 73-е місце з нижчим сумарним балом 2,55). У 2018 році Україна «повернулась» на позиції 2012 року - 66 місце у рейтингу з сумарним інтегральним індексом логістичної ефективності 2,83. Найгірший показник серед усіх оцінюваних характеристик Україна демонструвала за якістю митних процедур та якістю логістичної інфрраструктури з 2007 по 2018 рр.

Щодо міжнародних порівнянь у рейтингу логістичної ефективності 2018, слід зазначити, що Україна за своїм місцем розташувалася між Сербією і Єгиптом, а на пострадянському просторі стала третьою після Естонії (3,31 бала і 36 місце) і Литви (3,02 бала і 54 місце). Лідерство в рейтингу має Німеччина з сумарним показником LPI Score на рівні 4,2 бала. За нею йдуть Швеція, Бельгія, Австрія і Японія. Другу п'ятірку кращих складають Нідерланди, за якими йдуть Сінгапур, Данія, Велика Британія та Фінляндія.

Дослідження експертів Світового банку показують, що найменший індекс ефективності логістики припадає на країни зі слабкою і нестійкою економікою. Розрив між LPI країн з високим рівнем доходу та країн з низьким рівнем доходу, в середньому становить близько $45 \%$.

Отже, дані міжнародних рейтингів глобальної конкурентоспроможності та логістичної ефективності свідчать про взаємозв'язок їх результатів із станом та якістю логістики в країні. Ті країни, які розглядають логістику як стратегічну галузь, вживають активних заходів щодо скорочення логістичних витрат щодо внутрішнього валового продукту. У більшості розвинутих країн, які входять до топ-20 за вказаними рейтингами, логістичні витрати складають від 8 \% до 10 \% ВВП. Разом з тим, країни, що активно розвиваються (Китай, Індія, Туреччина, Казахстан), приділяють значну увагу залученню коштів для розвитку логістичної інфраструктури та спрощенню процедур міжнародної торгівлі, що сприяє зменшенню доданої вартості в сфрері логістики.

Загалом у цілому світі відзначається тенденція до більш високих темпів розвитку інфраструктурної складової в порівнянні з темпами зростання самих корпорацій. Ця тенденція пояснюється зростаючою значущістю інфрраструктурного забезпечення для підвищення ефективності економічної діяльності, високим мультиплікаційним ефектом збільшення попиту на послуги і низькою чутливістю інфраструктури до циклічних коливань економічної активності. Як наслідок, частка інвестування в інфрраструктурні проекти безперервно зростає [3].

Однак, як зазначає О.Карий та Г.Подвальна, з чим ми погоджуємося, проблема сьогодні не в тому, що логістична інфраструктура в Україні погіршується, а тому, що в загальному забезпечення логістичної діяльності в нашій державі розвивається повільніше ніж в інших країнах, що знижує інтегральну оцінку та місце в рейтингу.

Разом з тим, ми згодні з О.Поляковою та О.Шраменко [1], які вважають, що рейтинг LPI дещо суб'єктивний, оскільки методологічно оцінка ефективності логістики не є науково обґрунтованою. Означене пояснюється тим, що дослідження ґрунтується на результатах опитувань переважно міжнародних (транснаціональних) логістичних компаній. Однак, незважаючи на це, даний показник характеризує порівняльну характеристику країн і свідчить про достатньо низький рівень роз- витку вітчизняної логістичної інфраструктури при величезному логістичному потенціалі України.

Наприклад, об'єктивно встановлено, що логістичні витрати на перевезення зерна, ключового експортного товару України, з сільськогосподарських підприємств до портів Чорного моря приблизно на 40\% перевищують витрати на аналогічні послуги у Франції й Німеччині та є на 30\% вищими, ніж витрати в Сполучених Штатах. Як наслідок, сільгоспвиробники в Україні отримують меншу частку від світових ринкових цін та покривають витрати на неефективну логістику, які, за різними оцінками, призводять до втрати надходжень у розмірі від 600 млн дол. до 1600 млн дол. США щороку [16].

Отже, світовий досвід підтверджує, що країни з високим рівнем ефрективності логістики здатні забезпечувати підприємствам доступ на міжнародні ринки за допомогю надійних ланцюгів поставок. Країни з низькою логістичною ефективністю мають високі логістичні витрати, що негативно впливає на конкурентоспроможність національної економіки.

Підвищення обсягів експорту, імпорту та транзиту товарів територією України можливі лише завдяки комплексній транспортно-логістичній інфрастуктурі, в якій переважають залізничні магістралі для великогабаритних вантажів і перевезень на далекі відстані. Як відомо, у державі наявні 21700 км залізниць (з них більш як 47\% електрифіковано), 169500 км доріг, 2200 км внутрішніх водних шляхів (ВВШ) з 13 морськими (не включаючи 5 в Криму) та 10 річковими портами, склади (750 сертифікованих зернових складів), а також логістичні центри для полегшення виробництва, складування та транспортування товарів. Наявна потужність дозволяє транспортувати 1 млрд. тонн вантажів залізницею та 160 млн. т. через морські порти на рік. Окрім цього Україна є частиною кількох міжнародних транспортних коридорів, таких як коридори 3, 5, 7 і 9 Транс'європейської транспортної мережі (TENТ), коридори 3, 4, 5, 7, 8 і 10 Організації співробітництва залізниць (ОСЗ), а також частиною коридору Європа - Кавказ Азія (TRACECA). Проте наявна транспортна потужність недостатньо використовується, а відправники вантажоперевезень та постачальники логістичних послуг все ще мають справу 3 достатньо елементарною інфраструктурою та послугами, що відображається у високих витратах на логістику. Існуючі в Україні інфраструктурні об'єкти уже нездатні протистояти новим геоекономічним викликам та адаптуватися до стрімкого постіндустріального розвитку. Ми важаємо, що орієнтація на інноваційний шлях розвитку дозволить збільшити виробництво продукції з високою доданою цінністю, а ефективна логістика зробить їх більш конкурентоздатними на міжнародних ринках товарів і послуг.

Основними проблемами фактично всіх структурних елементів логістичної інфраструктури в Україні $€$ високий рівень її фізичного та морального зносу. Фактично логістична інфраструктура всіх видів транспорту роками належно не підтримувалася, не оновлювалася і зараз не відповідає вимогам міжнародних логістичних операторів. Іншою суттєвою проблемою формування цілісної логістичної інфрраструктури $€$ недостатність транспортно-логістичних центрів [3, с. 47]. Сучасна логістика передбачає не лише перевезення та зберігання вантажів, а й надання цілого комплексу додаткових послуг, пов'язаних як із митним оформленням товарів, так і 3 орендою офісних приміщень, обслуговуванням транспорту, мереж зв'язку та ін. [1, с. 85].

Тенденції розвитку світового ринку логістичних послуг 
показують, що за умов вільного руху транскордонних товаропотоків у межах інтегрованого ринку Європейського Союзу відбувається зменшення кількості національних терміналів та їх заміна єдиними міжнародними логістичними комплексами, що на практиці означає оптимізацію елементів інфраструктури. Одночасно з формуванням регіональних розподільчих центрів, великими компаніями-виробниками товарів створюються інфраструктурні об'єкти, що здійснюють накопичення, переробку, обслуговування, розподіл і поставку своїх товарів суб'єктам транскордонного співробітництва. Отже, спостерігається тенденція до консолідації транскордонних логістичних комплексів, об'єднання їх у міжнародні логістичні платформи, що сприяє ефрективному руху транскордонних товарних потоків [8].

Разом з тим, як показує світовий досвід, створення потужної національної транспортно-логістичної інфраструктури практично неможливе без підтримки держави, в тому числі взаємодії з держорганами, включаючи митницю, без партнерства з організаціями-вантажоперевізниками і іншими учасниками, що забезпечують логістичні процеси. В кожному конкретному випадку необхідний детальний аналіз можливих альтенатив інвестиційного забезпечення інфраструктурних проектів транспортно-логістичної системи з метою мінімізації можливих збитків для економіки загалом.

Усвідомлення значення логістики для економічного зростання держави сприяло створенню при Кабінеті Міністрів України у січні 2017 року логістичного комітету. До складу комітету увійшли представники Світового банку, різних міністерств і відомств, громадських організацій і бізнес-структур. Основна мета створення цього органу - це прискорення реформ транспортної інфраструктури України, а також залучення до постійного діалогу представників бізнесу та експертів. Оскільки Україна має вигідне географічне розташування на перехресті багатьох панєвропейських транспортних коридорів, має одну з найбільших у світі щільність залізниць, є морською та авіаційною державою, володіє значним транзитним і туристичним потенціалом, то для максимального використання цих потенційних можливостей необхідно консолідувати зусилля бізнесу і влади, а також сформувати оптимальний пакет інфрраструктурних проектів.

У червні 2018 року Міністерство інфрраструктури України спільно зі Світовим банком презентувало Стратегію сталої логістики для України на період до 2030 року. Логістична стратегія відповідає філософії Національної транспортної стратегії України 2030. Ключовою ідеєю Логістичної стратегії $€$ підвищення швидкості доставки вантажів з її одночасним здешевленням, запровадження сучасних технологій на транспорті, а також більш ефективне використання транзитного потенціалу України. При цьому Метою Стратегії сталої логістики є реалізація п'яти ключових завдань: реалізація потенціалу України в сфері логістики; посилення мультимодальності та взаємосполучуваності між різними видами транспорту; обслуговування, модернізація та розширення ефективної транспортної та логістичної інфраструктури, сприяння розвитку енергоесрективного вантажного транспорту; поліпшення навичок та послуг, пов'язаних з транспортом та логістикою; сприяння торгівлі.

Отже, нові парадигми економічного розвитку обумовлюють необхідність якісних змін і розвитку логістики в Україні. Досягнення поставленої мети може бути забезпечене різ- ними шляхами: радикальними змінами якості транспортної інфрраструктури, створенням дійсно конкурентного середовища на всіх видах транспорту, впровадженням останніх досягнень науково-технічного прогресу та інноваційних технологій мережевої взаємодії державних органів та бізнесу, впровадженням світових стандартів логістичного обслуговування та управління ланцюгами поставок, підвищенням рівня національної транспортної та екологічної безпеки.

\section{Висновки та перспективи подальших розвідок}

Таким чином, сказане вище свідчить, що розвиток глобальної логістики є закономірним і незаперечним процесом. Ключові позиції у сфері геоекономічної конкуренції займають ті країни, які сприймають логістику як фактор глобальної конкурентоспроможності національної економіки і приділяють значну увагу розвитку логістичної інфраструктури та ринку логістичних послуг.

Важливо підкреслити, що під час фрормування та розвитку транспортно-логістичної інфраструктури необхідно враховувати підсистему чинників, що впливають на їі фуннціонування (правова основа транспортно-логістичних відносин, конкурентне середовище, державна підтримка логістичної діяльності та інші). Важливе значення при цьому має державна підтримка транспортно-логістичної діяльності, що забезпечує рішення декількох практичних завдань. По-перше, це інвестування державою проектів розвитку логістичної інфрраструктури; по друге, це підсилення координації в розвитку транспортнологістичної інфраструктури окремих регіонів, країни в цілому.

Ключовим завданням, як визначено Стратегією, є необхідність покращення системи управління транспортно-логістичною інфраструктурою. На наш погляд, нова система управління повинна бути стратегічно орієнтованою. Стратегічно орієнтоване управління розвитком транспортно-логістичної інфраструктури повинно базуватися на оцінці потенціалу логістичної інфраструктури, виявленні зв'язків та залежності ії розвитку від організаційно-економічних, техніко-технологічних та інших можливостей. Сучасна інфраструктура, чесні ринкові умови та вільна ринкова конкуренція, ефективний розвиток і координація діяльності різних видів транспорту, разом із запровадженням ефективної системи державного регулювання та управління, забезпечать основу для розвитку та функціонального зростання національної транспортної системи України. Покращення ефективності, якості та рівня надання транспортних послуг дозволить підвищити конкурентоспроможність, стимулюватиме український експорт і сприятиме розвитку внутрішнього виробництва та торгівлі. Якісне управління логістичною інфрраструктурою дозволить провести діагностику логістичної інфраструктури, а саме - визначити ії складові елементи, провести їх оцінку, визначити зв'язки між елементами інфраструктури та на основі узагальнюючої оцінки транспортно-логістичної інфрраструктури розробити заходи щодо її розвитку та прийняття відповідних управлінських рішень.

Для максимального використання транспортного потенціалу України, зокрема й як транзитної держави, необхідно створити клієнторієнтовану систему транспортного обслуговування та вжити заходів щодо забезпечення ефективної організації роботи транспортно-дорожнього комплексу країни і отримати синергетичний ефект від ефективного поєднання потенціалу та можливостей усіх видів транспорту на основі партнерсько-конкурентних засад під час здійснення перевезень.

Вісник Сумського національного аграрного університету

Серія «Економіка і менеджмент», випуск 3 (81), 2019 


\section{Список використаної літератури:}

1. Полякова О. М., Шраменко О. В. Сучасні тенденції розвитку транспортно-логістичної інфрраструктури в Україні і світі. Вісник економіки транспорту і промисловості. 2017. Вип. 58. С. 126-134. URL: http://nbuv.gov.ua/UJRN/Vetp_2017_58_17

2. Гуржій Н. М., Городова А. В., Одинець Т. Є. Состояние и перспективы экономического развития предприятий транспортной инфраструктуры Украины. Економіка і суспільство. 2016. Випуск 3. С. 61-65.

3. Карий О. І., Подвальна Г. В. Логістична інфраструктура України у світових рейтингах. Вісник Національного університету «Львівська політехніка». Серія: Проблеми економіки та управління. Львів: Видавництво Львівської політехніки, 2017. № 873. С. 41-49.

4. Ковальська Л. Л. Транзитні транспортні потоки України: оцінка тенденцій та напрями оптимізації. Економічний форум. 2016. №4. C.53-58.

5. Крикавський Є.В. Логістичне управління. Львів: Вид-во НУ «Львівська політехніка», 2005. 384 с.

6. Павліха Н. Застосування логістичного підходу з метою управління потоками відходів в регіоні : Научные труды ДонНТУ. Серия економическая. Выпуск 75, 2004. С.138-145

7. Попова Н. В., Шинкаренко В. Г. Сучасні тенденції розвитку транспортно-логістичних систем. Вісник економіки транспорту і промисловості. 2016. № 53. С. 54-60.

8. Румянцев А. П., Яремович П. П. Інфраструктура транскордонних товарних потоків. Вісник Хмельницького національного університету. 2016. № 2, Том 1. С. 232-235.

9. Тарнавська Н. П., Сивак Р. Б. Організаційні та інфраструктурні передумови створення міжнародного логістичного центру. Бізнес-Інфоорм. 2013. № 13. С. 29-31.

10. Шостак Л. В. Формування логістичного потенціалу підприємства. Вісник Одеського національного університету. Серія: Економіка, 20 (4), С. 151-154.

11. Infrastructure and Trade: A Gravity Analysis for Major Trade Categories Using a New Index of Infrastructure.(2016). Julian Donaubauer, Alexander Glas, and Peter Nunnenkamp. Kiel Working Paper. 2016.

12. Global Logistics Market 2017-2021. Available at: URL: https://www.technavio.com/report/global-logistics-market-2017-2021

13. Arvis J.-F., Saslavsky D., Ojala L., Shepherd B. Connecting to Compete 2016. Trade Logistics in the Global Economy. The Logistics Performance Index and Its Indicators. Washington: Communications Development Incorporated, 2016. -62 p.

14. Agility Emerging Markets Logistics Index 2017. Interactive Map. - Access mode: URL: http://www.agility.com/EN/AboutUs/Pages/Emerging-Markets/ 2017/Interactive-Map.aspx.

15. The Logistics report 2019. Delivering safe, efficient, sustainable logistics. Freight Transport. 2019. URL: http://www.fta.co.uk/export/sites/fta/galleries/downloads/ logistics_report//r19-web-030619.pdf

16. World Bank (2015). Shifting into Higher Gear: Recommendations for Improved Grain Logistics in Ukraine

Bortnik S.M., PhD in Economics, Associate Professor, Lesya Ukrainka Eastern European National University (Lutsk, Ukraine)

Introduction. The transport system of Ukraine has a low level of development of logistics infrastructure and transport and logistics technologies in general, which reduces its competitiveness and limits the integration capabilities of our country in the world economic space. Ukraine needs urgent measures to improve the transport and logistics infrastructure, as it is outdated, inefficient; it requires renewal, modernization, significant investment and improvement of its management system. There is a need to adapt the concept of improving the logistics infrastructure to the needs of the Ukrainian market of transport and logistics services.

The purpose of the article is to demonstrate the place of Ukraine in the world rankings of logistics development and logistics infrastructure, as well as to analyze the reasons for the current results of our country in these rankings.

Results. It is established that the transport and logistics infrastructure is an important factor in the economic growth of any state. The concept of transport and logistics infrastructure and its components is specified. An assessment of the general state of logistics infrastructure development in Ukraine, as well as an assessment of the level of logistics potential use based on ratings of global competitiveness and logistics efficiency have been given. The place of Ukraine in the global rating of competitiveness in terms of the transport infrastructure quality, as well as the dynamics of logistics efficiency indicators of Ukraine are analyzed, international comparisons are made. The correlation of positions in international rankings of global competitiveness and logistics efficiency with the state and quality of logistics infrastructure in the country is proved.

Conclusions. Due to the analysis, the factors influencing the functioning and development of the transport and logistics infrastructure of Ukraine were identified. The need to improve the transport and logistics infrastructure management system has been proved. In order to ensure the synergetic effect of the effective combination of potential and capabilities of all modes of transport management of transport and logistics infrastructure should be strategically oriented and based on assessing the potential of logistics infrastructure, identifying links and dependence of its development on organizational, economic, technical and technological and other opportunities.

Key words: logistics, logistics efficiency, transport and logistics infrastructure, quality of logistics infrastructure, management of transport and logistics infrastructure development.

Дата надходження до редакції: 22.08.2019 р. 